\title{
Pielgrzymka do Jerozolimy w ujęciu Psalmu 122 (121)
}

\author{
ks. Janusz Wilk
}

Katowice

j.wilk@katowice.opoka.org.pl (D) https://orcid.org/0000-0002-6488-527X

Do istoty pielgrzymki przynależy ruch: wędrówka do miejsc świętych podejmowana z pobudek religijnych. Wiąże się z nią „trud pokonywania odległości dzielącej miejsce zamieszkania od sanktuarium ofiarowany Bogu z intencją oddania Mu czci, przebłagania za grzechy, podziękowania za otrzymane dary, a także uproszenia określonych łask”" W Izraelu czasu Starego Testamentu zjawisko pielgrzymowania „łączy się ściśle z rozpoznaniem, akceptacją, upamiętnieniem oraz ponawianym doświadczeniem obecności i działania Boga przez lud Jego wybrania”2.

Pielgrzymom zmierzającym do świątyni jerozolimskiej towarzyszyły niektóre psalmy, które były przez nich recytowane (śpiewane) podczas drogi lub

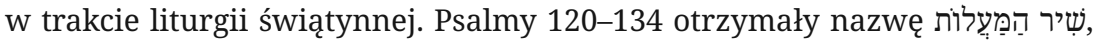

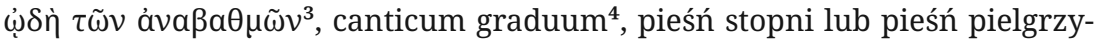
mów ${ }^{5}$. Gatunkowo nie są one jednolite, ale ich wspólną cechą jest szeroko rozumiany kult świątynny.

Proponowany jako przedmiot niniejszego studium Ps 122 przynależy do tej grupy i prawdopodobnie jest jednym z najbardziej znanych psalmów tego zbioru, wykorzystywany również podczas współczesnych pielgrzymek do Jeruzalem.

1 E. Sakowicz, Pielgrzymka, [w:] Encyklopedia katolicka, red. nacz. E. Gigilewicz, t. 15, Lublin 2011, kol. 480.

2 W. Chrostowski, Pielgrzymka w Biblii, [w:] Encyklopedia katolicka, dz. cyt., t. 15, kol. 482. Zob. także: J. Kozyra, Pielgrzymki w Biblii, „Śląskie Studia Historyczno-Teologiczne” 21 (1988), s. 5-18; T. Brzegowy, Izrael pielgrzymujący, „Tarnowskie Studia Teologiczne” 9 (1983), s. 37-51.

3 Septuaginta. Id est Vetus Testamentum graece iuxta LXX interpretes, edidit A. Rahlfs, t. 1-2, Stuttgart 1979.

4 Biblia Sacra. Iuxta vulgatam versionem, adiuvantibus B. Fischer [et al.], Stuttgart 1994.

5 Św. Augustyn nagłówek ten (jak i cały psalm) interpretuje alegorycznie, odnosząc go nie jako pielgrzymowanie do ziemskiej Jerozolimy - stolicy Judei, ale do „wiecznej Jerozolimy” w niebie zob. tenże, Objaśnienie psalmów. Ps 103-123, tł. J. Sulowski, oprac. E. Stanula, Warszawa 1986, s. 371 (Pisma Starochrześcijańskich Pisarzy, 41). 


\section{Propozycja przekładu Psalmu $122(121)^{6}$}

${ }^{1}$ Pieśń pielgrzymów. Dawida

Uradowałem się, gdy mi oznajmiono:

«Pójdziemy do Domu Jahwe».

${ }^{2}$ Stanęły nasze nogi

w twoich bramach, Jeruzalem!

${ }^{3}$ Jeruzalem, zbudowane jako miasto, w którym wszystko jest ze sobą zespolone.

${ }^{4}$ Tam przybywają pokolenia, pokolenia Jahwe zgodnie z prawem Izraela, aby wielbić Imię Jahwe.

${ }^{5}$ Tam bowiem wniesiono trony sędziowskie, trony dla domu Dawidowego.

${ }^{6}$ Błagajcie o pokój dla Jeruzalem, niech żyją w wolności, którzy cię miłują.

${ }^{7}$ Niech pokój będzie w twych murach, bezpieczeństwo w pałacach twoich.

${ }^{8}$ Ze względu na moich braci i przyjaciół będę wołał o pokój dla ciebie.

${ }^{9}$ Ze względu na Dom Jahwe - Boga naszego będę starał się o dobro dla ciebie.

\section{Struktura}

W psalmie wyraźnie dostrzegalne są trzy strofy, których tematyka nawiązuje do Jeruzalem. Nazwa świętego miasta (ירוּשָׁלְם znajduje się w każdej z trzech strof (w. 2, 3 i 6). Odpowiadają jej dwa wyrażenia, które ściśle związane z tym

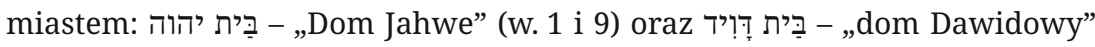
(w. 5). Oprócz powtórzeń „Jerozolima” i „dom” w tekście występują jeszcze

6 Przekład własny na podstawie Biblia Hebraica Stuttgartensia, oprac. K. Elliger, W. Rudolph, H. P. Rüger, Stuttgart 1990. 
dwa inne potrójne powtórzenia: imię יהוה (w. 1, 4 i 9) oraz שָׁלום - „pokój” (w. 6, 7 i 8). Potrójność ta wydaje się być zamierzona przez natchnionego autora, który podobnie jak orant Psalmu 99, aby wyeksponować jeden z przymiotów Bożych, trzykrotnie powtarza termin קָדוש - „święty” (Ps 99, 3. 5. 9; Iz 6, 3), tak też hagiograf Psalmu 122 trzykrotnie odwołuje się do najważniejszych aspektów w jego życiu (Jahwe, Jerozolima, dom, pokój) ${ }^{7}$.

Ze względu na tematykę utwór ten przynależy do grupy tzw. „pieśni o Syjonie”, w których przedmiotem czci jest Syjon - stolica królestwa Dawidowego i miejsce pobytu Arki Przymierza ${ }^{8}$. Opiewa on trzy aspekty pielgrzymki do Jeruzalem:

\begin{tabular}{|c|c|}
\hline Wersy & Tematyka \\
\hline $1 b c-2$ & Organizacja pielgrzymki i przybycie do Jerozolimy \\
\hline $3-5$ & Pochwała Jerozolimy \\
\hline $6-9$ & Życzenia dla Jerozolimy i jej mieszkańców \\
\hline
\end{tabular}

Psalm charakteryzuje się wewnętrzną jednością, tworząc układ symetrii chiastycznej:

\begin{tabular}{|c|c|c|}
\hline A & w. 1 & Odniesienie do „Domu Jahwe” \\
\hline B & w. $2-5$ & Charakterystyka Jerozolimy \\
\hline B' & w. $6-8$ & Życzenia dla Jerozolimy i jej mieszkańców \\
\hline A' & w. 9 & Odniesienie do „Domu Jahwe” \\
\hline
\end{tabular}

Idea „Domu Jahwe” scala utwór, ukierunkowując całą jego refleksję na najważniejsze miejsce w Jerozolimie - świątynię (A-A'). W tekście wyczuwalna jest ekspresja opisu tego wszystkiego, co znajduje się wokół świątyni, aktywności kolejnych pokoleń pielgrzymów (B) oraz gorliwa troska o losy zarówno samego miasta, jak i wszystkich jego mieszkańców oraz ludzi czasowo w nim przebywających (B').

7 Por. Salmos, traducción, introducciones y comentario L. Alonso Schökel, C. Cartniti, Estella 2009, t. 2: Salmos 73-150, s. 1478-1479. Szczegółowe studium kompozycji Ps 122 zob. L. Alonso Schökel, Salmo 122: Canto al nombre de Jerusalén, „Biblica” 61 (1980) nr 2, s. 236-240.

8 Por. S. Łach, Próba nowej interpretacji hymnów o Syjonie, „Studia Warmińskie” 12 (1975), s. 395-397. Zbiór tych hymnów tworzą Psalmy 46, 48, 76, 84, 87 i 122. 


\section{Czas powstania pieśni}

Informacja zawarta w nagłówku utożsamia ten utwór z osobą króla Dawida (לְְדוֹד). Nie jest ona jednak wiarygodna, gdyż orant eksponuje istnienie świątyni jerozolimskiej oraz silnie rozwinięty wokół niej ruch pielgrzymkowy, tymczasem w okresie Dawida świątyni jeszcze nie było. Łączenie psalmu z królem Dawidem mogło stanowić pośrednie opowiedzenie się hagiografa za dynastią, której protoplastą był ten król (zob. także w. 5: „dom Dawidowy”)

Noty tej brak jest w dwóch hebrajskich manuskryptach, najstarszym tekście LXX oraz w Targumie ${ }^{10}$. Aktualnie rozpiętość propozycji datacji powstania tego utworu sięga z jednej strony czasów Salomona, a z drugiej czasów machabejskich ${ }^{11}$.

\section{Etapy pielgrzymki do Jeruzalem}

Chociaż nie możemy dokładnie określić ani autora, ani okresu powstania tego utworu, możemy jednak przyjąć, że zrodził się on pod wpływem pielgrzymki, jaką orant podjął wraz ze swoimi bliskimi (może mieszkańcami tej samej miejscowości, regionu) do świętego miasta Jeruzalem. Po powrocie, utrwalając swoje natchnione przemyślenia, spisał dla siebie i potomnych tekst, który ostatecznie otrzymał kształt Psalmu $122^{12}$. Stanowił on (i wciąż stanowi)

9 Por. J. H. Eaton, Psalms. Introduction and Commentary, London 1967, s. 281 (Torch Bible Commentaries).

10 Zob. aparat krytyczny Biblia Hebraica Stuttgartensia.

11 Zob. prezentację współczesnych autorów opowiadających się za konkretnym czasem powstania tego psalmu - S. Gądecki, „Proście o pokój dla Jeruzalem” (Ps 122, 6), [w:] Problematyka pokoju u papieży Jana XXIII i Jana Pawła II. Sympozjum zorganizowane przez Katedrę Teologii Wspótczesnej Wydziału Teologicznego Uniwersytetu Kardynała Stefana Wyszyńskiego. Warszawa, 15 października 2003 r., pod red. J. Lewandowskiego, Ząbki 2004, s. 74-75. Wymowny (obrazowy) komentarz do czasu powstania tego psalmu zaproponował Izaak Cylkow (opowiadając się za okresem po niewoli babilońskiej jako czasem powstania tej pieśni): „Starcy pozostający na wygnaniu żegnają karawanę wyruszających do odbudowanej na nowo Jerozolimy Izraelitów, przypominając sobie z tęsknotą pierwszą swoją młodość, kiedy wspólnie z ojcami swoimi pielgrzymowali do owej wspaniałej stolicy, będącej centralnym punktem religijnego i politycznego życia narodu" (Psalmy, tł. I. Cylkow, Kraków-Budapeszt 2008, s. 369).

12 Por. Psalms III. 101-150, introduction, translation and notes with an appendix, the grammar of the psalter by M. Dahood, Garden City 1970, s. 203 (The Anchor Bible, 17A). 
pewnego rodzaju wykładnię pielgrzymowania do Jerozolimy. Uniwersalność i ponadczasowość tych słów pozwala wyróżnić trzy aspekty tej drogi.

\subsection{Organizacja pielgrzymki i przybycie do Jerozolimy (w. 1bc-2)}

Pierwsza część Psalmu 122 odnosi się do dwóch skrajnych momentów pielgrzymki: zapowiedzi wyjścia (w. 1bc) oraz momentu dotarcia do celu (w. 2). Psalmista pominął opis trudu wędrowania, jakby chciał pokazać, że sama droga nie wymaga dodatkowej refleksji. Ważny jest bowiem cel-Jerozolima i znajdujący się w niej בִּית יהוה (,Dom Jahwe”). Już sama myśl o nim przysparza orantowi radości (שמח, w. 1b). W tej formie postrzegania rzeczywistości również wymagająca wysiłku i dłuższego zaangażowania droga będzie dla pielgrzyma radością (zob. Iz 30, 29).

W postawie radości hagiograf odsłania swoją gorliwość wiary. Jego radość nie jest czymś przelotnym (jak zadowolenie i przyjemność), ale czymś bardziej trwałym, związanym nie tyle ze sferą posiadania, co bycia ${ }^{13}$. Prawdopodobnie należał on do grupy tych wyznawców Jahwe, którzy za każdym razem, ilekroć w miejscu jego zamieszkania organizowano pielgrzymkę do Jeruzalem, odczuwali ten stan ducha. Stąd wersy 1 bc można również przetłumaczyć: „Raduję się zawsze, gdy mi mówią”14. Być może odległość od świętego miasta (np. z Galilei) nie pozwalała hagiografowi na częstsze w nim odwiedziny.

Orant nie precyzuje, z okazji którego wielkiego święta (Pascha; Święto Tygodni; Święto Namiotów) ${ }^{15}$ lokalni przywódcy religijni organizowali pielgrzymkę, ale podkreśla wspólnotowość tego przedsięwzięcia (zob. także Iz 2, 3; Jr 31, 6; Mi 4, 2). Wypowiada się najpierw we własnym imieniu, ukazując swoją reakcję na wieść o planowanej wędrówce ku Jerozolimie (w. 1b), by po chwili stać się rzecznikiem całej wspólnoty, która dotarła już do bram Jeruzalem (w. 1c-2). Tak dobrany język nie gloryfikuje natchnionego autora, ale podkreśla jego więź ze współwyznawcami. Wspólnotowość, w której nie rozmywa się poszczególny człowiek, uwydatnia, że razem nie tylko jest łatwiej

13 Por. M. Laetitia, Tajemnica radości, przekł. T. Jania, Kraków 1993, s. 13-14.

14 W. A. VanGemeren, Psalms, [w:] The Expositor's Bible commentary. With The New international version of the Holy Bible, general editor F. E. Gaebelein, associate editor R. P. Polcyn, consulting editors W. C. Kaiser [et al.], t. 5: Psalms-Song of Songs, Grand Rapids 1991, s. 775.

15 Zob. A. Paciorek, Najstarsze święta w Izraelu, [w:] Życie religijne w Biblii, red. G. Witaszek, Lublin 1999, s. 307-329; T. Brzegowy, Doroczne święta pielgrzymkowe Izraela, „Ruch Biblijny i Liturgiczny” 36 (1983), s. 98-115, https://doi.org/10.21906/rbl.904. 
znosić trudy podróży, ale i przeżywać dar wiary. Indywidualizm w wierze jest równie niebezpieczny jak egoizm w miłości ${ }^{16}$.

Dotarcie do bram miasta (w. 2; por. Ps $84,3.8$ ) i spojrzenie na Jeruzalem, będące zarówno religijną, jak i polityczno-kulturową stolicą narodu wybranego, przekształca radość oranta w zachwyt, który zaowocował uroczystą pieśnią na cześć Syjonu. Głosy pielgrzymów znajdujących się u bram miasta ${ }^{17}$ zespoliły się w chór wychwalający Syjon. To już nie tylko radość dotarcia, ale przede wszystkim radość spotkania.

\subsection{Pochwała Jerozolimy (w. 3-5)}

Psalmista w analizowanej pieśni wychwala trzy charakterystyczne przymioty miasta. Pierwszym z nich jest jego piękno urbanistyczne wyrażone w solidności budowli i harmonii ich rozmieszczenia (w. 3) ${ }^{18}$. W swojej potędze Jerozolima była fortecą zapewniającą bezpieczeństwo i azyl (zob. np. Ps 48 i 87), a w swej delikatności i pięknie uosabiała dziewczynę, która zachwycała i przyciągała do siebie lud (zob. Ps 84$)^{19}$. Wszystko to powodowało, że pielgrzym przybywający po raz pierwszy do tego miasta mógł doznać zachwytu, a ten, kto odwiedzał je po raz kolejny, utrwalał w sobie jego piękno i majestat. Psalmista był jednym z nich.

Drugim przymiotem Jerozolimy jest status centrum religijnego wszystkich pokoleń Izraela (w. 4). Tylko to miasto cieszyło się mianem גִיר אֶלהֵינוּ (,miasto naszego Boga” - Ps 48, 2). Poszczególne pokolenia (rody) narodu wybranego pomimo różnorodności miejsca zamieszkania i okresu życia posiadały (i posiadają) świadomość, że są שְִׁבטָי־יָה (,pokoleniami Jahwe” - w. 4), które na Syjonie powinny wielbić Jahwe (zob. Ps 65, 2).

W psalmiście wyczuwalna jest zarówno silna więź ze wszystkimi, którzy przez wieki stanowili poszczególne „pokolenia Jahwe”, jak i duma religijna. Kocha to miasto, gdyż jest ono umiłowanym miejscem Jahwe i równocześnie

16 Por. J. Wilk, Psalm 122. O pielgrzymce do świętego miasta Jeruzalem, „Apostolstwo Chorych” 2015 nr 2, s. 16.

17 W okresie funkcjonowania pierwszej świątyni (tzw. Salomona), bramy świątyni były jednocześnie bramami miasta - zob. S. Gądecki, „Proście o pokój dla Jeruzalem” (Ps 122, 6), dz. cyt., s. 77; T. Jelonek, Dzieje świątyni jerozolimskiej, Kraków 2004, s. 21-24.

18 Zob. więcej: D. Bahat, Atlas biblijnej Jerozolimy, oprac. wyd. polskiego W. Chrostowski, przekł. E. Czerwińska, Warszawa 1999 (Prymasowska Seria Biblijna, 11).

19 Por. Salmos, dz. cyt., t. 2, s. 1482. 
miejscem, gdzie wszyscy jego rodacy mogą „wielbić Imię Jahwe”20. Zostali wezwani do tego przez samego Boga (zob. Wj 23, 14-17; Pwt 12, 5-6; 16, 16-17).

Trzecią cechą miasta, którą wyeksponował orant, jest jego funkcja sądowniczo-administracyjna (w. 5). Plastycznie wyraził to przez sformułowa-

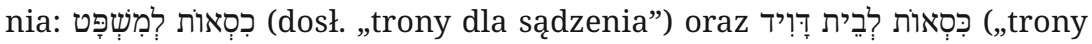
domu Dawida”). Pierwszy z tronów odzwierciedla troskę o sprawiedliwość, i to zarówno w wymiarze społecznym (zob. 2 Sm 15, 1-6; 23, 3-4; $1 \mathrm{Krl} \mathrm{7,} \mathrm{7;}$ Iz 1, 21-26), jak i religijnym (zob. Ps 50; Iz 1, 10-20; Jr 7) ${ }^{21}$. Drugi podkreśla rolę dynastii Dawida w historii całego Izraela. Dynastia ta jest gwarancją boskiego i społecznego porządku w Izraelu (zob. 2 Sm 8, 15; Ps 101; Jr 21, 12).

Obydwa trony symbolizowała również architektura miasta - w pobliżu świątyni jerozolimskiej (symbol prawości) znajdował się pałac królewski (symbol dynastii Dawidowej). W Jerozolimie spotkała się teologia Syjonu z teologią królestwa (zob. Ps 2, 6; 122; 132) 22 .

\section{3. Życzenia dla Jerozolimy i jej mieszkańców (w. 6-9)}

W ostatniej części psalmu (w. 6-8) dominuje idea pokoju (نשֶׁ). Leksem ten w swoim polu semantycznym posiada również terminy: „dobrobyt” i „nienaruszalność”23. Psalmista, przybywając do Jeruzalem, korzysta zatem nie tylko z tradycyjnej formy pozdrowienia (zob. np. 1 Sm 25, 6; Mt 10, 12-13), ale uzewnętrznia również swoje przywiązanie i życzliwość dla Jeruzalem oraz jego mieszkańców. Życzy im pokoju, który przeradza się w dobrobyt i pełną suwerenność. Powodzenie oraz bezpieczeństwo Jerozolimy oznaczało błogosławieństwo i pokój dla całej społeczności Izraela ${ }^{24}$.

$\mathrm{W}$ wersach tych relacja pomiędzy psalmistą a Jerozolimą wydaje się być więzią oblubieńca i oblubienicy, co wyrażają między innymi zaimki

20 Por. A. Klawek, Modlitwa za Święte Miasto, „Ruch Biblijny i Liturgiczny” 2 (1949) nr 4, s. 228, https://doi.org/10.21906/rbl.2374.

21 „Prawdopodobnie wprowadzenie monarchii Dawidowej nie usunęło całkowicie sędziowskiej władzy naczelników pokoleń czy przełożonych przy różnych sanktuariach lokalnych, ale sądy królewskie stanowiły instancję apelacyjną” - Księga Psalmów. Wstęp, przekład z oryginału, komentarz, ekskursy, oprac. S. Łach, przygotował do druku J. Łach, Poznań 1990, s. 520 (Pismo Święte Starego Testamentu, 7.2).

22 Por. L. C. Allen, Psalms 101-150, revised, Dallas 2002, s. 214 (Word Biblical Commentary, 21).

23 Zob. שָלוֹם, [w:] L. Koehler, W. Baumgartner, J. J. Stamm, Wielki stownik hebrajsko-polski i aramejsko-polski Starego Testamentu, red. nauk. wyd. polskiego P. Dec, Warszawa 2008, t. 2, s. 490-493 (Prymasowska Seria Biblijna, 30).

24 L. C. Allen, Psalms 101-150, dz. cyt., s. 214. 


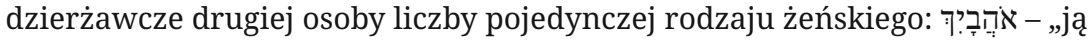

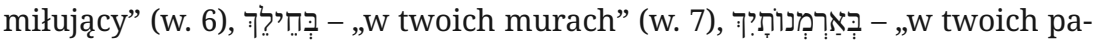

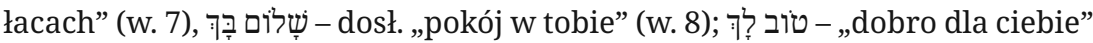
(w. 9) ${ }^{25}$. Natchniony wieszcz czterokrotnie ułożył z nich rym na końcach wersów, a raz na końcu półwiersza (w. 7), co nie jest powszechnym zjawiskiem w poezji hebrajskiej - jakby chciał przejrzyście i dogłębnie wyrazić swoją miłość wobec Jeruzalem.

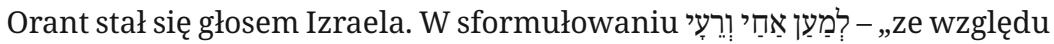
na moich braci i przyjaciół” (w. 8) wypowiedział się w imieniu wszystkich pokoleń Izraela (zob. Ml 2, 10) lub też w imieniu braci, którzy nie mogli wraz z nim wyruszyć na pielgrzymkę do świętego miasta ${ }^{26}$. Prosi dla Jerozolimy, aby stało się miastem pokoju (טָׁלוֹ, w. w) i 9); aby jego nazwa odpowiadała temu, co dzieje się w jego wnętrzu ${ }^{27}$.

\section{Refleksja podsumowująca}

Psalmista, który z Bożego natchnienia ułożył sto dwudziestą drugą pieśń psałterza, był głęboko praktykującym wyznawcą Jahwe. Jego więź z Bogiem wyrażała się między innymi przez pielgrzymki do Jerozolimy - miasta, które Bóg wybrał na szczególne miejsce, gdzie człowiek mógł wielbić Jego Imię (zob. w. 4).

Orant, wędrując do Jeruzalem, nie realizował wyłącznie nakazu religijnego (zob. Wj 23, 14-17; Pwt 12, 5-6; 16, 16-17). Był człowiekiem, dla którego już sama informacja o planowanej pielgrzymce przysparzała radości (zob. w. 1), co świadczy o jego intensywnej relacji z Jahwe. Zewnętrzna forma pielgrzymki wyrażała jego wewnętrzny stan, odzwierciedlała jego duchowe bogactwo.

25 Por. I Salmi, nuova versione, introduzione e commento di T. Lorenzin, Milano 2008, s. 481 (I Libri Biblici. Primo Testamento, 20).

26 Por. G. Ravasi, Psalmy, cz. 4: Psalmy 104-123 (wybór), przeł. K. Stopa, Kraków 2009, s. 348-349 (Zgłębiać Biblię).

27 Nazwa „Jerozolima” jest pochodzenia semickiego. Jego etymologia jest jednak niejasna. Wśród wyjaśnień tego terminu znaleźć można następujące znaczenia: „założone przez (boga) Szalem”; „posiadłość Szalema” (legendarnego założyciela tego miasta lub określenie miasta, w którym czczono bóstwo Szalem) oraz „miasto pokoju” - zob. P. C. Bosak, Leksykon wszystkich miejsc biblijnych, Kraków 2016, s. 460. Zob. także rozważanie Benedykta XVI dotyczące tej kwestii - tenże, Psalm 122 - święte miasto Jeruzalem, „L’Osservatore Romano” wydanie polskie $2006 \mathrm{nr} 2$, s. 53-54. Warto zapoznać się z całościowym opracowaniem historii Jerozolimy: S. Sebag-Montefiore, Jerozolima. Biografia, przekł. M. Antosiewicz, W. Jeżewski, Warszawa 2011. 
Psalm 122 nie jest jednak bezpośrednią modlitwą psalmisty do Boga, ale wypowiedzią skierowaną do jego ukochanego miasta. Miłość ta wypływała nie z estetycznej wrażliwości oranta, ale z jego miłości do Jahwe, będącego gospodarzem tego miejsca.

Pielgrzymując do Syjonu, hagiograf słuchał Boga, starał się „zrozumieć” Jego zamysł dotyczący Jeruzalem łączącego w sobie teokrację z monarchią. Psalmista był silnie związany z „Domem Jahwe” (w. 1. 9) i równocześnie obdarzał szacunkiem „dom Dawida” (w. 5). Te dwa domy były zwornikami dla całego Izraela i wszystkich pielgrzymów, zarówno tych, którzy wędrowali dosłownie, jak i tych, którzy z różnych przyczyn nie mogli wyruszyć w drogę. Hagiograf odczuwał wspólnotę z jednymi i drugimi (zob. w. 8). W imieniu ich wszystkich modlił się, aby symboliczna nazwa „Jerozolima” („miasto pokoju") charakteryzowała faktyczny stan miasta (w. 8-9). Los całego narodu był bowiem ściśle złączony z losem Jerozolimy. Pokój i dobrobyt w tym mieście oznaczał pokój i dobrobyt w całym narodzie wybranym i odwrotnie. Orant modlił się jednak o pokój dla Jerozolimy nie w kontekście zależności, ale miłości.

Prawdopodobnie w czasach Chrystusa psalm ten był również recytowany (śpiewany) przez pielgrzymów zmierzających do Jerozolimy. Można przypuszczać, że modlił się nim sam Jezus. W połączeniu z przesłaniem tej pieśni można domyślać się, ile wewnętrznego bólu musiały zawierać słowa Chrystusa zapowiadające upadek tego miasta (zob. Łk 19, 41-44). Płacz Jezusa jest tego najlepszym wyrazem (zob. Łk 19, 41). Bóg nie pozbawił jednak Jeruzalem nadziei (zob. Łk 21, 24).

Coraz częściej psalm ten jest recytowany przez współczesnych pielgrzymów wyruszających z różnych zakątków świata do Jerozolimy. Możliwość pielgrzymki do tego miasta (i całego Izraela) dla wielu jest powodem prawdziwej radości (zob. w. 1). Chociaż nie ma już w Jerozolimie „Domu Jahwe” (w. 1. 9) i „domu Dawidowego” (w. 5), jest jednak Ziemia Święta, po której stąpał Bóg, który stał się człowiekiem w Jezusie Chrystusie. Każda pielgrzymka do tego miasta przeżywana z wiarą była i jest czasem łaski dla pielgrzymującego oraz dla tych, których pątnik duchowo ze sobą zabrał (zob. w. 8). Wciąż też jest aktualna i potrzebna modlitwa o pokój (zob. w. 8) i dobro (zob. w. 9) dla Jerozolimy oraz jej mieszkańców. Ostatecznie wciąż jest to miejsce wybrane przez Boga. 


\section{Abstrakt}

\section{Pielgrzymka do Jerozolimy w ujęciu Psalmu 122 (121)}

W artykule podjęto analizę Psalmu 122 z perspektywy zjawiska pielgrzymkowego w starożytnym Izraelu. Prawdopodobnie utwór ten zrodził się pod wpływem pielgrzymki, jaką psalmista podjął wraz ze swoimi bliskimi do Jerozolimy. Po powrocie, utrwalając swoje natchnione przemyślenia, spisał dla siebie i potomnych tekst, który ostatecznie otrzymał kształt Psalmu 122. Stanowi on pewnego rodzaju wykładnię pielgrzymowania do Jerozolimy. Uniwersalność i ponadczasowość tych słów pozwala wyróżnić w nim trzy aspekty pielgrzymiej drogi: (1) Organizacja pielgrzymki i przybycie do Jerozolimy (w. 1bc-2), (2) Pochwała Jerozolimy (w. 3-5), (3) Życzenia dla Jerozolimy i jej mieszkańców (w. 6-9), które stały się przedmiotem studium niniejszego opracowania.

Słowa kluczowe: Psalm 122; Jerozolima; pielgrzymka; radość; dom; pokój

\section{Abstract}

\section{The Pilgrimage to Jerusalem in the Psalm's Depiction 122 (121)}

The article takes up the analysis of Psalm 122 from the perspective of the pilgrimage phenomenon in old Israel. Probably it was created by the influx of pilgrimage which the psalmist made to Jerusalem together with his relatives. After the return, fixing his thoughts in his mind, he wrote for himself as well as for the future generations a text, which at the end was formed as a Psalm 122. It is by some part an explanation of pilgrimage to Jerusalem. Universality and timelessness of the words given allows to distinguish in it three aspects of the pilgrimage road: (1) Organising and coming to Jerusalem (v. 1bc-2), (2) Praise of Jerusalem (v. 3-5), (3) Wishes for Jerusalem and its citizens (v. 6-9) that became the subject of the present analysis.

Keywords: Psalm 122; Jerusalem; pilgrimage; joy; house; peace

\section{References}

Allen, L. C. (2002). Psalms 101-150, revised. Nashville: T. Nelson.

Alonso Schökel, L., \& Carniti, C. (2009). Salmos. 2: Salmos 73-150 (4a edición, 2a reimpresión). Estella: Editorial Verbo Divino.

Augustyn. (1986). Objaśnienia psalmów. Ps 103-123. (E. Stanula, Ed., J. Sulowski, Trans.). Warszawa: Akademia Teologii Katolickiej.

Bahat, D. (1999). Atlas biblijnej Jerozolimy. (Waldemar Chrostowski, Ed., E. Czerwińska, Trans.). Warszawa: Vocatio. Benedykt XVI. (2006). Psalm 122 - święte miasto Jeruzalem. L'Osservatore Romano. Wydanie Polskie, (2), 53-54. Bosak, P. C. (2016). Leksykon wszystkich miejsc biblijnych. Kraków: Wydawnictwo Petrus.

Brzegowy, T. (1983). Izrael pielgrzymujący. Tarnowskie Studia Teologiczne, 9, 37-51.

Brzegowy, T. (1983). Doroczne święta pielgrzymkowe Izraela. Ruch Biblijny i Liturgiczny, 36(2), 98-115. https:// doi.org/10.21906/rbl.904

Chrostowski, W. (2011). Pielgrzymka w Biblii. In E. Gigilewicz (Ed.), Encyklopedia katolicka (1st ed., Vol. 15, pp. 482-485). Lublin: Towarzystwo Naukowe Katolickiego Uniwersytetu Lubelskiego.

Cylkow, I. (Ed.). (2008). Psalmy. Kraków-Budapeszt: Wydawnictwo Austeria. 
Dahood, M. J. (1970). Psalms III. 101-150 (1st ed.). Garden City: Doubleday.

Eaton, J. H. (1967). Psalms. Introduction and commentary. London.

Fischer, B. (Ed.). (1994). Biblia Sacra. Iuxta Vulgatam versionem. Stuttgart: Deutsche Bibelgesellschaft.

Gądecki, S. (2004). „Proście o pokój dla Jeruzalem” (Ps 122, 6). In J. Lewandowski (Ed.), Problematyka pokoju u papieży Jana XXIII i Jana Pawła II. Sympozjum zorganizowane przez Katedrę Teologii Wspótczesnej Wydziału Teologicznego Uniwersytetu Kardynała Stefana Wyszyńskiego, Warszawa, 15 października 2003 r. Ząbki: Apostolicum.

Jelonek, T. (2004). Dzieje świątyni jerozolimskiej. Kraków: Wydawnictwo WAM.

Kittel, R., Bardtke, H., \& Schenker, A. (Eds.). (1990). Biblia Hebraica Stuttgartensia. Stuttgart: Deutsche Bibelgesellschaft.

Klawek, A. (1949). Modlitwa za Święte Miasto. Ruch Biblijny i Liturgiczny, 2(4), 227-229. https://doi.org/10.21906/ rbl. 2374

Köhler, L., Baumgartner, W., \& Stamm, J. J. (2008). שִׁלום. P. Dec (Ed.), Wielki stownik hebrajsko-polski i aramejsko-polski Starego Testamentu (Vol. 2). Warszawa: Oficyna Wydawnicza Vocatio.

Kozyra, J. (1988). Pielgrzymki w Biblii. Śląskie Studia Historyczno-Teologiczne, 21, 5-18.

Łach, J., \& Łach, S. (Eds.). (1990). Księga Psalmów. Wstęp, przekład z oryginału, komentarz, ekskursy. Poznań: Pallottinum.

Łach, S. (1975). Próba nowej interpretacji hymnów o Syjonie. Studia Warmińskie, 12, 395-405.

Lorenzin, T. (Ed.). (2008). I Salmi (3rd ed.). Milano: Paoline.

Marie-Laetitia. (1993). Tajemnica radości. (T. Jania, Trans.). Kraków: Wydawnictwo M.

Paciorek, A. (1999). Najstarsze święta w Izraelu. In G. Witaszek (Ed.), Życie religijne w Biblii (pp. 307-329). Lublin: Redakcja Wydawnictw KUL.

Rahlfs, A. (1979). Septuaginta. Id est Vetus Testamentum graece iuxta LXX interpretes. Stuttgart: Deutsche Bibelgesellschaft.

Ravasi, G., \& Stopa, K. (2009). Psalmy. Cz. 4: Psalmy 104-123 (wybór). Kraków: Wydawnictwo Salwator.

Sakowicz, E. (2011). Pielgrzymka. In E. Gigilewicz (Ed.), Encyklopedia katolicka (1st ed., Vol. 15, pp. 480-482). Lublin: Towarzystwo Naukowe Katolickiego Uniwersytetu Lubelskiego.

Schökel, L. A. (1980). Salmo 122: Canto al nombre de Jerusalén. Biblica, 61(2), 234-250.

Sebag Montefiore, S. (2011). Jerozolima. Biografia. (M. Antosiewicz \& W. Jeżewski, Trans.). Warszawa: Wydawnictwo Magnum.

VanGemeren, W. A. (1991). Psalms. In F. E. Gaebelein, R. P. Polcyn, \& W. C. Kaiser (Eds.), The Expositor's Bible commentary. With The New international version of the Holy Bible. Vol. 5: Psalms-Song of Songs (pp. 1-880). Grand Rapids: Zondervan.

Wilk, J. (2015). Psalm 122. O pielgrzymce do świętego miasta Jeruzalem. Apostolstwo Chorych, (2), 16-18. 